JURNAL NOMINAL / VOLUME VIII NOMOR 1 / TAHUN 2019

\title{
PENGARUH PEMAHAMAN KODE ETIK PROFESI AKUNTAN DAN KECERDASAN MAHASISWA TERHADAP PERILAKU ETIS MAHASISWA AKUNTANSI UNIVERSITAS NEGERI DI YOGYAKARTA.
}

\author{
Nur Anwar Musyadad \\ Program Studi Akuntansi Universitas Negeri Yogyakarta \\ anwarmusyadad96@gmail.com \\ Endra Murti Sagoro \\ Staf Pengajar Jurusan Pendidikan Akuntansi Universitas Negeri Yogyakarta
}

\begin{abstract}
Abstrak : Pengaruh Pemahaman Kode Etik Profesi Akuntan Dan Kecerdasan Mahasiswa Terhadap Perilaku Etis Mahasiswa Akuntansi Universitas Negeri Di Yogyakarta. Penelitian ini bertujuan untuk mengetahui pengaruh Pemahaman Kode Etik Profesi Akuntan dan Kecerdasan Mahasiswa terhadap Perilaku Etis Mahasiswa Akuntansi Universitas Negeri di Yogyakarta. Jenis penelitian ini adalah kuantitatif. Populasi pada penelitian ini yaitu mahasiswa S1 Akuntansi pada tiga Perguruan Tinggi Negeri di Yogyakarta. Sampel dalam penelitian ini sebesar 273 diambil dengan metode proportionate random sampling. Teknik pengambilan data yang digunakan dalam penelitian ini adalah kuesioner yang telah diuji validitas dan reliabilitasnya. Teknik analisis data yang digunakan adalah analisis regresi sederhana dan analisis regresi berganda yang didahului dengan uji normalitas, uji multikolinieritas serta uji heteroskedastisitas. Hasil penelitian ini menunjukkan bahwa (1) Pemahaman Kode Etik Profesi akuntan berpengaruh positif signifikan terhadap Perilaku Etis mahasiswa; (2) Kecerdasan Intelektual berpengaruh positif signifikan terhadap Perilaku Etis mahasiswa; (3) Kecerdasan Emosional berpengaruh positif signifikan terhadap Perilaku Etis mahasiswa; (4) Kecerdasan Spiritual berpengaruh positif signifikan terhadap Perilaku Etis mahasiswa; (5) Pemahaman Kode Etik Profesi akuntan, Kecerdasan Intelektual, Kecerdasan Emosional, dan Kecerdasan Spiritual secara simultan berpengaruh positif signifikan terhadap Perilaku Etis mahasiswa.
\end{abstract}

Kata Kunci: Kode Etik Profesi Akuntan, Kecerdasan Intelektual, Kecerdasan Emosional, Kecerdasan Spiritual, Perilaku Etis.

\begin{abstract}
The Influence Of Understanding Code Ethic Of Accounting Profession And Student's Intelegence To The Ethical Behaviour Of Accounting Student Of State University In Yogyakarta. This study aims to determine the effect of Understanding the Code Ethics of Accounting Profession and Student's Intelligence to the Ethical Behavior of Accounting Students of State University in Yogyakarta. The population in research are S1 Accounting students Three State University in Yogyakarta. The number of respondents amounted to 273 students with proporsionate random sampling. The instrument used in this research is a questionnaire with validity and reliability test. Data analysis techniques used are simple regression analysis and multiple regression analysis, in addition to both the analysis the researchers also tested normality test, multicollinearity test and heteroscedasticity test. The results of this research indicate that (1) Understanding Code of Ethics Profession accountant has a significant positive effect on Student Ethical Behavior;(2) Intellectual Intelligence has a significant positive effect on Student Ethical Behavior;(3) Emotional Intelligence has a significant positive effect on Student Ethical Behavior;(4) Spiritual Intelligence has a significant positive effect on Student Ethical Behavior;(5)Understanding of Code of Ethics Accountant profession, Intellectual Intelligence, Emotional Intelligence, and Spiritual Intelligence simultaneously have a significant positive effect on Student Ethical Behavior.
\end{abstract}

Keywords: Code of Professional Ethics of Accountants, Intellectual Intelligence, Emotional Intelligence, Spiritual Intelligence, Ethical Behavior. 


\section{JURNAL NOMINAL / VOLUME VIII NOMOR 1 / TAHUN 2019}

\section{PENDAHULUAN}

Peran seorang mahasiswa dalam kemajuan perekonomian negara tidak kalah penting dengan komponen lain seperti relasi perekonomian negara, perputaran serta jumlah uang yang beredar pada masyarakat. Mahasiswa memiliki peran dalam menjunjung tinggi nama negara dengan melakukan hal yang terbaik, khususnya mahasiswa akuntansi dalam pengungkapan pertanggungjawaban pelaporan keuangan. Kasus penyimpangan perilaku seorang akuntan juga pernah dilakukan oleh beberapa peneliti, salah satunya Hendri \& Suyanto (2014), dalam penelitian ini kecurangan yang dipermasalahkan adalah pelanggaran tentang standar dan aturan serta kode etis profesi akuntansi pada perusahaanperusahaan besar seperti Enron, WordlCom, serta Tyco.

Penelitian tentang faktor-faktor yang mempengaruhi perilaku etis seseorang telah dilakukan peneliti terdahulu seperti Nugrahaningsih (2005) yang menggunakan beberapa komponen diantaranya yaitu gender (jenis kelamin seseorang), usia, pendidikan, serta tingkat moralitas Etika merupakan pembelajaran mengenai tindakan moral atau kode berperilaku yang mengikutinya, menurut Kamus Besar Bahasa Indonesia, etika mempunyai tiga makna yang salah satu diantaranya yaitu nilai mengenai benar dan salah sesuatu yang dianut dalam masyarakat. Menurut (Suseno, 1987), etika juga dapat di definisikan sebagai filsafat atau pemikiran yang mendasar mengenai ajaran dan pandangan moral. Menurut Kinicki \& Kreitner (2001), perilaku etis dan perilaku tidak etis merupakan suatu produk atas kombinasi yang cukup rumit dari berbagai pengaruh.

Davis \& Welton (1991) dalam penelitiannya yang berjudul "Profesional Ethics: Business Student's Perceptions" menunjukkan hasil yang berbeda dengan penelitian sebelumnya yaitu terlihat bahwa kode etik tidak berpengaruh terhadap professional ethics. Dalam penelitian tersebut professional ethics merupakan akibat dari perilaku yang dilakukan oleh seseorang dengan segala keputusannya untuk melakukan perilaku etis atau tidak etis.

Kecerdasan intelektual memiliki presentase faktor kesuksesan seseorang sebesar $20 \%$ saja, sedangkan sisanya yaitu $80 \%$ ditentukan dengan kekuatan lain seperti kelas sosial, nasib, dan doa. Beberapa kekuatan lain tersebut yang kemungkinan akan didapatkan dengan adanya kecerdasan emosional serta kecerdasan spiritual (Goleman, 2007: 44). Menurut Melandy dan Aziza (2006), kecerdasan emosional merupakan 


\section{JURNAL NOMINAL / VOLUME VIII NOMOR 1 / TAHUN 2019}

kecerdasan untuk menggunakan emosi sesuai keinginan seseorang, kemampuan mengendalikan emosi sehingga dapat memberikan dampak positif, kecerdasan emosional berkontribusi cukup besar dalam pemcapaian kebahagiaan dan kesejahteraan. Zohar dan Marshall (2007), mendefinisikan kecerdasan spiritual sebagai kemampuan ataupun kecerdasan dalam menghadapi perihal makna, yaitu menempatkan perilalku dan hidup seseorang dalam konteks makna yang lebih luas untuk menilai tindakan ataupun jalan hidup seseorang lebih bermakna dibanding dengan kehidupan orang lain. Risela (2016) mendefinisikan Kecerdasan Spiritual adalah kemampuan individu untuk menyesuaikan diri terhadap situasi baru. Mahasiswa yang memiliki kecerdasan spiritual yang tinggi akan selalu mengedepankan makna-makna positif dalam setiap tindakan yang akan dilakukan sehingga perilaku etis akan selalu melekat pada diri mahasiswa.

Berbagai masalah terkait dengan perilaku etis sudah banyak terjadi seperti penyimpangan keuangan di suatu negara. Perilaku penyimpangan tidak hanya terjadi pada ruang lingkup yang besar saja, tetapi juga banyak terjadi di bangku perkuliahan. Menurut Sagoro (2013) kecurangan akademik adalah salah satu perilaku tidak etis yang terjadi di perguruan tinggi yaitu diantaranya mencontek saat ujian, menyalin (copy paste) jawaban teman, menyalin dari internet tanpa menyebutkan sumbernya, plagiarisme, titip tanda tangan kehadiran, mempersiapkan contekan untuk ujian, menyalin tugas teman, bertanya kepada teman saat ujian atau kuis, melirik atau melihat jawaban teman, memberitahu jawaban kepada teman saat ujian atau kuis. Dalam penelitian yang dilakukan oleh Forgas dan Negre (2010) banyak terjadi perilaku tidak etis di lingkungan akademik, salah satunya adalah plagiarisme yang dilakukan karena adanya anggapan "plagiarism : Internet make easy". Menurut Forgas dan Negre (2010) plagiarisme terjadi karena adanya peluang yang diberikan oleh teknologi informasi yang semakin canggih sehingga dapat dengan mudah melakukan copy paste informasi yang tersedia tanpa menyertakan sumbernya.

Mahasiswa masih saling berlombalomba agar mendapatkan prestasi akademik dengan memperoleh nilai yang bagus dengan cara yang tidak etis seperti mencontek saat ujian dan kuis. Menurut Irawati (2008) mahasiswa melakukan kecurangan akademik dengan sengaja, salah satunya pelanggaran terhadap aturan dalam penyelesaian tugas dan ujian, memberikan keuntungan kepada pelajar lain dalam mengerjakan tugas atau ujian 
dengan cara yang tidak jujur. Kurnia (2008) meneliti faktor tindakan kecurangan yang dilakukan oleh mahasiswa untuk memperoleh nilai IPK yang tinggi yaitu karna ada tekanan dari orang tua, teman maupun dirinya sendiri agar terlihat lebih sukses dalam akademik dan merasa percaya diri pada temantemanya. Dalam jangka panjang jika hal ini dibiarkan berlangsung maka akan lahir para lulusan sarjana yang tidak memiliki integritas yang baik.

\section{METODE PENELITIAN}

\section{Jenis Penelitian}

Penelitian ini menggunakan jenis penelitian survei. Penelitian survei merupakan penelitian yang mengambil sampel dari populasi serta menggunakan instrumen penelitian berupa kuesioner. Penelitian survei juga merupakan bagian dari metode penelitian diskriptif kuantitatif yang digunakan untuk mencari unsur, ciriciri, serta sifat-sifat suatu fenomena. Penelitian survei ini dilakukan dengan memulai untuk mencari data, mengumpulkan, dan menganalisis data (Suryana, 2010: 20). Dalam penelitian ini, peneliti menggunakan bentuk penelitian kausal komparatif, yaitu salah satu bentuk penelitian yang bertujuan untuk menyelidiki kemungkinan sebab-akibat terjadinya suatu fenomena (Suryana, 2010: 18).

\section{Waktu dan Tempat Penelitian}

Penelitian ini dilaksanakan di 3 Progam Studi Akuntansi Perguruan Tinggi Negeri di Yogyakarta Waktu penelitian dilaksanakan pada Maret - Juni 2018.

\section{Populasi dan Sampel}

Populasi pada penelitian ini yaitu mahasiswa S1 Akuntansi 3 Perguruan Tinggi Negeri di Yogyakarta yang berjumlauh 856 mahasiswa. Sampel yang diambil menggunakan teknik proporsionate random sampling sehingga diperoleh sebanyak 273 mahasiswa.

\section{Data, Intrumen, dan Teknik}

\section{Pengumpulan Data}

Jenis data yang digunakan dalam penelitian ini adalah data kuantitatif. Sumber data yang digunakan adalah data primer. Data yang digunakan dalam penelitian ini menggunakan data primer, yang diperoleh melalui penyebaran kuisioner. Kuisioner merupakan teknik pengumpulan data yang dilakukan dengan cara memberi seperangkat pertanyaan atau pernyataan tertulis kepada responden untuk dijawabnya (Husein Umar, 2011: 49)

\section{Teknik Analisis Data}

Uji Prasyarat Analisis yang dilakukan dalam penelitian ini adalah Uji Normalitas, Uji Multikolinearitas, dan Uji 


\section{JURNAL NOMINAL / VOLUME VIII NOMOR 1 / TAHUN 2019}

Heterokedastisitas. Uji Prasyarat Analisis dilakukan sebelum melakukan uji hipotesis penelitian. Penelitian ini menggunakan analisis statistik deskriptif untuk memberikan gambaran mengenai data penelitian supaya data yang tampilkan mudah dipahami dan informatif. Uji hipotesis dalam penelitian ini dilakukan dengan menggunakan analisis regresi linear sederhana dan analisis regresi linear berganda. Tingkat signifikansi yang ditetapkan dalam penelitian ini adalah sebesar 5\% $(\alpha=0,05)$. Analisis data penelitian menggunakan bantuan suatu program komputer pengolah data statistik.

\section{HASIL PENELITIAN DAN PEMBAHASAN}

1) Uji Deskriptif

a) Deskriptif Data Responden

Berdasarkan data dari bagian akademik, jumlah populasi dalam penelitian ini adalah 856 mahasiswa jurusan Akuntansi 3 Universitas Negeri di Yogyakarta. Berdasarkan jumlah keseluruhan tersebut, peneliti menyebarkan kuesioner sebanyak 273 eksemplar. Total keseluruhan kuesioner yang disebarkan memiliki pengembalian $100 \%$.

b) Deskriptif Perilaku Etis Mahasiswa Hasil data yang diperoleh diketahui Perilaku Etis memiliki nilai maksimal
32, nilai minimal 18 , mean 25,28 dan standar deviasi 3,05. Berdasarkan data tersebut, hasil distribusi kecenderungan data variabel Perilaku Etis dapat dilihat sebagai berikut:

\begin{tabular}{cccc}
\hline $\begin{array}{c}\text { Kategor } \\
\text { i }\end{array}$ & Interval & $\begin{array}{c}\text { Freku } \\
\text { ensi }\end{array}$ & $\begin{array}{c}\text { Present } \\
\text { ase }\end{array}$ \\
\hline Tinggi & $\mathrm{X}>24$ & 180 & $65 \%$ \\
\hline Sedang & $16 \leq \mathrm{X} \leq 24$ & 93 & $35 \%$ \\
\hline Rendah & $\mathrm{X}<16$ & 0 & 0 \\
\hline \multicolumn{2}{c}{ Jumlah } & 273 & $100 \%$ \\
\hline
\end{tabular}

Tabel 1. Kategori Kecenderungan Data Perilaku Etis (Sumber : Data Primer Diolah, 2018)

Berdasarkan tabel 1, dapat disimpulkan bahwa penilaian responden terhadap Perilaku Etis adalah tinggi.

\section{c) Deskriptif Pemahaman Kode etik} Profesi Akuntan

Hasil data yang diperoleh diketahui Pemahaman Kode Etik Profesi Akuntan memiliki nilai maksimal 96, nilai minimal 68, mean 79,10 dan standar deviasi 7,87. Berdasarkan data tersebut, hasil distribusi kecenderungan data variabel Pemahaman Kode Etik Profesi Akuntan dapat dilihat sebagai berikut:

\begin{tabular}{cccc}
\hline $\begin{array}{c}\text { Kategor } \\
\text { i }\end{array}$ & Interval & $\begin{array}{c}\text { Freku } \\
\text { ensi }\end{array}$ & $\begin{array}{c}\text { Present } \\
\text { ase }\end{array}$ \\
\hline Tinggi & $\mathrm{X}>72$ & 202 & $73 \%$ \\
\hline Sedang & $48 \leq \mathrm{X} \leq 72$ & 71 & $27 \%$ \\
\hline Rendah & $\mathrm{X}<48$ & 0 & 0 \\
\hline Jumlah & 273 & $100 \%$ \\
\hline
\end{tabular}


Tabel 2. Kategori Kecenderungan Data Pemahaman Kode etik Profesi Akuntan (Sumber : Data Primer Diolah, 2018)

Berdasarkan tabel 2, dapat disimpulkan bahwa penilaian responden terhadap Pemahaman Kode Etik Profesi Akuntan adalah tinggi.

\section{d) Deskriptif Kecerdasan Intelektual}

Hasil data yang diperoleh diketahui Kecerdasan Intelektual memiliki nilai maksimal 40, nilai minimal 23, mean 30,99 dan standar deviasi 3,87. Berdasarkan data tersebut, hasil distribusi kecenderungan data variabel Kecerdasan Intelektual dapat dilihat sebagai berikut:

\begin{tabular}{cccc}
\hline $\begin{array}{c}\text { Kategor } \\
\text { i }\end{array}$ & Interval & $\begin{array}{c}\text { Freku } \\
\text { ensi }\end{array}$ & $\begin{array}{c}\text { Present } \\
\text { ase }\end{array}$ \\
\hline Tinggi & $\mathrm{X}>30$ & 132 & $48 \%$ \\
\hline Sedang & $20 \leq \mathrm{X} \leq 30$ & 141 & $52 \%$ \\
\hline Rendah & $\mathrm{X}<20$ & 0 & 0 \\
\hline \multicolumn{2}{c}{ Jumlah } & 273 & $100 \%$ \\
\hline
\end{tabular}

Tabel 3. Kategori Kecenderungan Data

Kecerdasan Intelektual Sumber : Data Primer Diolah, 2018

Berdasarkan tabel 3, dapat disimpulkan bahwa penilaian responden terhadap Kecerdasan Intelektual adalah sedang.

\section{e) Deskriptif Kecerdasan Emosional}

Hasil data yang diperoleh diketahui Kecerdasan Emosional nilai maksimal 79, nilai minimal 44 , mean 56,35 dan standar deviasi 6,58. Berdasarkan data tersebut, hasil distribusi kecenderungan data variabel Kecerdasan Emosional dapat dilihat sebagai berikut:

\begin{tabular}{cccc}
\hline $\begin{array}{c}\text { Kategor } \\
\text { i }\end{array}$ & Interval & $\begin{array}{c}\text { Freku } \\
\text { ensi }\end{array}$ & $\begin{array}{c}\text { Present } \\
\text { ase }\end{array}$ \\
\hline Tinggi & $\mathrm{X}>60$ & 41 & $15 \%$ \\
\hline Sedang & $40 \leq \mathrm{X} \leq 60$ & 232 & $85 \%$ \\
\hline Rendah & $\mathrm{X}<40$ & 0 & 0 \\
\hline \multicolumn{2}{c}{ Jumlah } & 273 & $100 \%$ \\
\hline
\end{tabular}

Tabel 4. Kategori Kecenderungan Data

Kecerdasan Emosional (Sumber : Data

Primer Diolah, 2018)

Berdasarkan tabel 4, dapat disimpulkan bahwa penilaian responden terhadap Kecerdasan Emosional adalah sedang.

\section{f) Deskriptif Kecerdasan Spiritual}

Hasil data yang diperoleh diketahui Kecerdasan Spiritual nilai maksimal 66, nilai minimal 41 , mean 52,35 dan standar deviasi 4,37. Berdasarkan data tersebut, hasil distribusi kecenderungan data variabel Kecerdasan Spiritual dapat dilihat sebagai berikut:

\begin{tabular}{cccl}
\hline $\begin{array}{c}\text { Kategor } \\
\text { i }\end{array}$ & Interval & $\begin{array}{c}\text { Freku } \\
\text { ensi }\end{array}$ & $\begin{array}{l}\text { Present } \\
\text { ase }\end{array}$ \\
\hline Tinggi & $X>51$ & 129 & $47 \%$ \\
\hline Sedang & $34 \leq \mathrm{X} \leq 51$ & 144 & $53 \%$ \\
\hline Rendah & $\mathrm{X}<34$ & 0 & 0 \\
\hline Jumlah & 273 & $100 \%$ \\
\hline
\end{tabular}

Tabel 5. Kategori Kecenderungan Data Kecerdasan Spiritual (Sumber : Data Primer Diolah, 2018)

Berdasarkan tabel 5, dapat disimpulkan bahwa penilaian responden terhadap Kecerdasan Spiritual adalah sedang. 


\section{Hasil Uji Asumsi Klasik}

\section{1) Uji Normalitas}

Uji normalitas dilakukan untuk mengetahui data yang digunakan untuk penelitian terdistribusi normal atau tidak. Uji normalitas dilakukan dengan uji Kolmogorov smirnov sehingga diperoleh angka signifikansi sebesar 0,304. Angka tersebut lebih besar 0,05 yang menunjukkan bahwa data dalam penelitian ini terdistribusi normal.

\section{2) Uji Heteroskedastisitas}

Uji heteroskedastisitas bertujuan untuk mengetahui model regresi terjadi ketidaksamaan variance dari residual satu pengamatan ke pengamatan yang lain atau tidak (Ghozali,2013).

Berikut ini adalah hasil uji analisis Heteroskedastisitas:

\begin{tabular}{lc}
\hline \multicolumn{1}{c}{ Variabel } & Signifikansi \\
\hline $\begin{array}{l}\text { Pemahaman Kode Etik } \\
\text { Profesi Akuntan }\end{array}$ & 0,459 \\
\hline Kecerdasan Intelektual & 0,339 \\
\hline Kecerdasan Emosional & 0,434 \\
\hline Kecerdasan Spiritual & 0,470 \\
\hline Tabel 6: Hasil uji Heteroskedastisitas
\end{tabular}
(Sumber : Data Primer Diolah, 2018)

Berdasarkan Tabel 6, nilai signifikansi lebih besar dari 0,05, Hal ini berarti tidak terjadi heteroskedastisitas.

\section{3) Uji Multikolinieritas}

Uji multikolonieritas bertujuan untuk menguji suatu model regresi ditemukan adanya korelasi antar variabel bebas (independen). Model regresi yang baik yaitu model regresi yang tidak memilikikorelasi antar sesama variabel bebas (Ghozali,2013).

Berikut ini adalah hasil uji analisis Multikolinieritas:

\begin{tabular}{lc}
\hline \multicolumn{1}{c}{ Variabel } & Nilai VIF \\
\hline $\begin{array}{l}\text { Pemahaman Kode Etik } \\
\text { Profesi Akuntan }\end{array}$ & 1,820 \\
\hline Kecerdasan Intelektual & 3,233 \\
\hline Kecerdasan Emosional & 2,818 \\
\hline Kecerdasan Spiritual & 2,430 \\
\hline Tabel 7. Hasil & Pengujian
\end{tabular}
Multikolinieritas (Sumber : Data Primer Diolah, 2018)

Berdasarkan tabel 7, diketahui tidak terjadi multikolinearitas. Hal ini dapat dilihat dari nilai VIF dari masingmasing variabel kurang dari 10.

\section{Hasil Pengujian Hipotesis dan Pembahasan}

\section{Uji Regresi Sederhana}

Regresi sederhana didasarkan pada hubungan fungsional ataupun kausal satu variabel indenpenden dengan satu variabel dependen. Uji ini digunakan untuk mengetahui pengaruh variabel Pemahaman Kode Etik Profesi Akuntan, Kecerdasan Intelektual, Kecerdasan Emosional, Dan Kecerdasan Spiritual terhadap Perilaku Etis Mahasiswa secara parsial.

Pengaruh Pemahaman Kode Etik Profesi Akuntan terhadap Perilaku Etis Mahasiswa 


\section{JURNAL NOMINAL / VOLUME VIII NOMOR 1 / TAHUN 2019}

Hasil rangkuman analisis regresi linear sederhana adalah sebagai berikut :

\begin{tabular}{lc}
\hline \multicolumn{1}{c}{ Keterangan } & Nilai \\
\hline Koefisien Regresi & 0,253 \\
\hline Konstanta & 4,191 \\
\hline $\mathbf{R}$ & 0,653 \\
\hline $\boldsymbol{R}$ Square & 0,427 \\
\hline $\mathbf{T}$ & 14,198 \\
\hline $\mathbf{t}_{\text {table }}$ & 1,968 \\
\hline Sig & 0,000 \\
\hline
\end{tabular}

Tabel 8. Hasil Uji Regresi 1 (Sumber :

Data Primer Diolah, 2018)

Berdasarkan tabel 8 diperoleh hasil persamaan Regresi Linier Sederhana sebagai berikut:

$$
\mathrm{Y}=4,191+0,253 \mathrm{X}_{1}
$$

Berdasarkan dari hasil tersebut menunjukkan arah model regresi ini adalah positif dengan nilai koefisien korelasi (R) sebesar 0,653, artinya semakin besar nilai dari Pemahaman Kode Etik Profesi Akuntan maka semakin besar pula nilai Perilaku Etis Mahasiswa Universitas Negeri di Yogyakarta atau semakin kecil nilai dari Pemahaman Kode Etik Profesi Akuntan maka semakin kecil pula nilai Perilaku Etis Mahasiswa Universitas Negeri di Yogyakarta. variabel pemahaman kode etik profesi akuntan memiliki nilai t sebesar 14,198 dengan signifikansi 0,000 . Nilai signifikansi $0,000<0.05$ dan dapat disimpulkan bahwa pemahaman kode etik profesi akuntan memiliki pengaruh positif signifikan terhadap perilaku etis mahasiswa.
Hasil penelitian tersebut didukung oleh Ernawati \& Susanti (2016) dimana dalam penelitian tersebut terdapat hasil bahwa variabel pemahaman Kode Etik Profesi Akuntan memiliki pengaruh positif signifikan terhadap Perilaku Etis Mahasiswa Akuntansi. Jenifer, \& Moruku (2014) dalam penelitiannya yang berjudul Ethics and Role of Accountants yang menunjukkan hasil bahwa terdapat pengaruh peraturan atau kode etik atas profesi akuntan dalam praktek pekerjaan sebagai seorang akuntan. Schwartz (2001) dalam penelitiannya berjudul "The Nature of the Relationship between Corporate Code of ethics and behaviour" menunjukkan hasil bahwa kode etik merupakan fakktor yang sangat potensial untuk mempengaruhi perilaku etis. Hal tersebut membuktikan bahwa dalam perkuliahan dibutuhkan pemahaman kode etik profesi sehingga seseorang dalam bekerja akan dengan mudah menyesuaikan diri terhadap aturan dalam setiap profesi yang dimiliki.

\section{Pengaruh Kecerdasan Intelektual}

\section{Terhadap Perilaku Etis Mahasiswa}

Hasil rangkuman analisis regresi linear sederhana adalah sebagai berikut : 
JURNAL NOMINAL / VOLUME VIII NOMOR 1 / TAHUN 2019

\begin{tabular}{lc}
\hline \multicolumn{1}{c}{ Keterangan } & Nilai \\
\hline Koefisien Regresi & 0,431 \\
\hline Konstanta & 11,922 \\
\hline $\mathbf{R}$ & 0,547 \\
\hline $\boldsymbol{R}$ Square & 0,300 \\
\hline $\mathbf{T}$ & 10,768 \\
\hline $\mathbf{t}_{\text {table }}$ & 1,968 \\
\hline Sig & 0,000 \\
\hline
\end{tabular}

Tabel 9. Hasil Uji Regresi 2 (Sumber :

Data Primer Diolah, 2018)

Berdasarkan tabel 9 diperoleh hasil persamaan Regresi Linier Sederhana sebagai berikut:

$$
\mathrm{Y}=11,922+0,431 \mathrm{X}_{2 \mathrm{a}}
$$

Berdasarkan dari hasil tersebut menunjukkan arah model regresi ini adalah positif dengan nilai koefisien korelasi (R) sebesar 0,547, artinya semakin besar nilai dari Kecerdasan Intelektual maka semakin besar pula nilai Perilaku Etis Mahasiswa Universitas Negeri di Yogyakarta atau semakin kecil nilai dari Kecerdasan Intelektual maka semakin kecil pula nilai Perilaku Etis Mahasiswa Universitas Negeri di Yogyakarta. Variabel Kecerdasan Intelektual memiliki nilai $\mathrm{t}$ sebesar 10,768 dengan signifikansi 0,000. Nilai signifikansi $0,000<0.05$ dan dapat disimpulakan bahwa kecerdasan intelektual memiliki pengaruh positif signifikan terhadap perilaku etis mahasiswa.

Menurut Goleman (2007) dalam penelitianya, Kecerdasan intelektual memiliki presentase faktor kesuksesan seseorang sebesar $20 \%$ saja, sedangkan sisanya yaitu $80 \%$ ditentukan dengan kekuatan lain seperti kelas sosial, nasib, dan doa. Beberapa kekuatan lain tersebut yang kemungkinan akan didapatkan dengan adanya kecerdasan emosional serta kecerdasan spiritual. Hasil penelitian tersebut didukung oleh Jamaluddin \& Indriasari (2011) dimana dalam penelitian tersebut terdapat hasil bahwa variabel kecerdasan intelektual memiliki pengaruh positif signifikan terhadap Perilaku Etis Mahasiswa Akuntansi. Dalam penelitian Jamaluddin \& Indriasari (2011) menjelaskan bahwa semakin tinggi kecerdasan intelektual mahasiswa maka semakin baik etika mahasiswa. Dengan pernyataan tersebut mengindikasikan bahwa mahasiswa yang memiliki kececrdasan intelektual yang tinggi maka akan menjadikan seorang mahasiswa berperilaku etis dalam menghadapi segala masalah yang dihadapi dengan adanya pertimbangan logika yang baik. Aprilianto \& Achmad (2017) menunjukkan dalam hasil penelitian mereka bahwa semakin tinggi kecerdasan intelektual mahasiswa maka akan memiliki pengaruh besar terhadap persepsi mahasiswa dalam bertindak secara etis. Dengan adanya beberapa penelitian yang hasil penelitiannya sejalan dengan penelitian ini membuktikan bahwa hipotesis penelitian 
ini terbukti terdapat pengaruh antara Kecerdasan Intelektual mahasiswa terhadap perilaku etis mahasiswa.

\section{Pengaruh Kecerdasan Emosional}

Terhadap Perilaku Etis Mahasiswa

Hasil rangkuman analisis regresi linear sederhana adalah sebagai berikut :

\begin{tabular}{lc}
\hline \multicolumn{1}{c}{ Ketrangan } & Nilai \\
\hline Koefisien Regresi & 0,227 \\
\hline Konstanta & 12,502 \\
\hline $\mathbf{R}$ & 0,489 \\
\hline $\boldsymbol{R}$ Square & 0,240 \\
\hline $\mathbf{t}$ & 9,240 \\
\hline $\mathbf{t}_{\text {table }}$ & 1,968 \\
\hline Sig & 0,000 \\
\hline
\end{tabular}

Tabel 10. Hasil Uji Regresi 3 (Sumber :

Data Primer Diolah, 2018)

Berdasarkan tabel 10 diperoleh hasil persamaan Regresi Linier Sederhana sebagai berikut:

$$
\mathrm{Y}=12,502+0,227 \mathrm{X}_{2 \mathrm{~b}}
$$

Berdasarkan dari hasil tersebut menunjukkan arah model regresi ini adalah positif dengan nilai koefisien korelasi (R) sebesar 0,489, artinya semakin besar nilai dari Kecerdasan Emosional maka semakin besar pula nilai Perilaku Etis Mahasiswa Universitas Negeri di Yogyakarta atau semakin kecil nilai dari Kecerdasan Emosional maka semakin kecil pula nilai Perilaku Etis Mahasiswa Universitas Negeri di Yogyakarta. Variabel Kecerdasan Emosional memiliki nilai $\mathrm{t}$ sebesar 9,240 dengan signifikansi 0,000. Nilai signifikansi $0,000<0.05$ dan dapat disimpulakan bahwa Kecerdasan
Emosional memiliki pengaruh positif signifikan terhadap Perilaku Etis mahasiswa.

Hasil penelitian tersebut didukung oleh Lucyanda (2012) dalam penelitiannya menemukan hasil penelitian bahwa kececrdasan yang paling dominan mempengaruhi perilaku etis adalah kecerdasan emosional, hal tersebut dikarenakan kecerdasan lain yang dimiliki seseorang mmerupakan bagian dari karakter individu yang berkembang bersamaan dengan kecerdasan emosional,. Dalam penelitian Simanjorang \& Sipayung (2012) dijelaskan bahwa dijelaskan bahwa semakin tinggi kecerdasan Emosional mahasiswa maka semakin baik Perilaku Etis Mahasiswa Akuntansi tersebut. Kecerdasan Emosional adalah kemampuan individu untuk menyesuaikan diri terhadap situasi baru. mahasiswa yang memiliki kecerdasan emosional yang baik maka dirinya mampu menerima, menilai dan mengontrol emosi dirinya dengan baik sehingga memiliki perilaku etis yang baik. Hasil penelitian ini juga diperkuat dengan pernyataan yang ada di dalam penelitian Istiqamah (2012) yang menyatakan bahwa seorang mahasiswa dengan kecerdasan tinggi akan membantu mahasiswa mengelola emosinya dengan lebih baik sehingga berdampak pada perilaku yang akan dilakukan mahasiswa. Dapat ditarik 


\section{JURNAL NOMINAL / VOLUME VIII NOMOR 1 / TAHUN 2019}

kesimpulan bahwa dengan adanya beberapa hasil penelitian sebelumnya terlihat mendukung hipotesis penelitian ini membuktikan jika kecerdasan emosional mahasiswa baik maka perilaku etis mahasiswa juga akan semakin baik.

\section{Pengaruh Kecerdasan Spiritual}

\section{Terhadap Perilaku Etis Mahasiswa}

Hasil rangkuman analisis regresi linear sederhana adalah sebagai berikut :

\begin{tabular}{lc}
\hline \multicolumn{1}{c}{ Keterangan } & Nilai \\
\hline Koefisien Regresi & 0,342 \\
\hline Konstanta & 7,357 \\
\hline $\mathbf{R}$ & 0,491 \\
\hline $\boldsymbol{R}$ Square & 0,241 \\
\hline $\mathbf{T}$ & 9,277 \\
\hline $\mathbf{t}_{\text {table }}$ & 1,968 \\
\hline Sig & 0,000 \\
\hline
\end{tabular}

Tabel 11. Hasil Uji Regresi 3 (Sumber :

Data Primer Diolah, 2018)

Berdasarkan tabel 11 diperoleh hasil persamaan Regresi Linier Sederhana sebagai berikut:

$$
\mathrm{Y}=7,357+0,342 \mathrm{X}_{2 \mathrm{c}}
$$

Berdasarkan dari hasil tersebut menunjukkan arah model regresi ini adalah positif dengan nilai koefisien korelasi (R) sebesar 0,491. artinya semakin besar nilai dari Kecerdasan Spiritual maka semakin besar pula nilai Perilaku Etis Mahasiswa Universitas Negeri di Yogyakarta atau semakin kecil nilai dari Spiritual maka semakin kecil pula nilai Perilaku Etis Mahasiswa Universitas Negeri di Yogyakarta. Variabel Kecerdasan Spiritual memiliki nilai $\mathrm{t}$ sebesar 9,277 dengan signifikansi 0,000. Nilai signifikansi 0,000 < 0.05 dan dapat disimpulakan bahwa kecerdasan spiritual memiliki pengaruh positif signifikan terhadap perilaku etis mahasiswa.

Hasil penelitian tersebut mendukung penelitian yang dilakukan oleh Riasning, Datrini \& Putra (2017) dimana dalam penelitian tersebut terdapat hasil bahwa variabel kecerdasan Spiritual memiliki pengaruh positif signifikan terhadap Perilaku Etis Mahasiswa Akuntansi. Beberapa peneliti lainnya juga mendukung hasil penelitian pada hipotesis ini, diantaranya yaitu Handayani (2016) dalam penelitiannya yang berjudul Faktor Faktor yang Mempengaruhi Perilaku Etis Mahasiswa Akuntansi Universitas Islam Lamongan yang menunjukkan hasil bahwa kecerdasan spiritual mahasiswa yang semakin baik pada mahasiswa akuntansi semakin baik perilaku etis mahasiswa.. Penelitian ini juga telah didukung hasil penelitian sebelumnya yang dilakukan oleh Umar (2012) yang menjelaskan bahwa kecerdasan spiritual dalam dunia pekerjaan merupakan kecerdasan yang dibutuhkan sejak berada pada bangku perkuliahan untuk selalu dipersiapkan, hal tersebut terjadi karena menjadi seorang akuntan maupun auditor serta beberapa profesi lain membutuhkan dasar pemikiran 
yang disertai dengan makna dan manfaat bukan hanya untuk dirinya sendiri namun untuk semua orang yang berkepentingan di sekitarnya.

\section{Uji Regresi Berganda}

Analisis regresi linier berganda yaitu suatu analisis suatu asosiasi yang digunakan secara bersamaan untuk meneliti pengaruh dua variabel atau lebih terhadap satu variabel yang tergantung dengan skala interval. Hasil rangkuman analisis regresi linear berganda adalah sebagai berikut :

\begin{tabular}{lr}
\hline \multicolumn{1}{c}{ Variabel } & \multicolumn{1}{c}{ Nilai } \\
\hline Konstanta & 2,100 \\
\hline $\begin{array}{l}\text { Pemahaman Kode Etik } \\
\text { Profesi Akuntan }\end{array}$ & 0,193 \\
\hline Kecerdasan Intelektual & 0,090 \\
\hline Kecerdasan Emosional & 0,050 \\
\hline Kecerdasan Spiritual & 0,028 \\
\hline $\mathbf{R}$ & 0,679 \\
\hline $\boldsymbol{R}$ Square & 0,461 \\
\hline Adjusted $\boldsymbol{R}$ Square & 0,453 \\
\hline F Hitung & 57,241 \\
\hline Sig F & 0,000 \\
\hline Tabel 12. Hasil Uji Regresi & Simultan
\end{tabular}

(Sumber : Data Primer Diolah, 2018)

Berdasarkan tabel 11 diperoleh hasil persamaan Regresi Linier Berganda sebagai berikut:

$Y=2,100+0,193 \mathrm{X} 1_{1}+0,090 \mathrm{X}_{2 \mathrm{a}}+0,050 \mathrm{X}_{2 \mathrm{~b}}+$ $0,028 \mathrm{X}_{2 \mathrm{c}}$

Berdasarkan dari hasil tersebut menunjukkan arah model regresi ini adalah positif dengan nilai koefisien korelasi (R) sebesar 0,679. Koefisien Adjusted R
Square sebesar 0,453, hal ini menunjukkan 45,3\% Perilaku Etis Mahasiswa Akuntansi Universitas Negeri di Yogyakarta dipengaruhi oleh Pemahaman Kode Etik Profesi Akuntan, Kecerdasan Intelektual, Kecerdasan Emosional dan Kecerdasan Spiritual, sedangkan sisanya sebesar $54,7 \%$ dipengaruhi oleh variabel lain di luar penelitian ini.diperoleh nilai $\mathrm{F}$ sebesar 57,241 nilai signifikansi sebesar 0,000 yang berarti lebih kecil dari level of signifikan yaitu $0,050(0,000<0,050)$.

Berdasarkan hasil tersebut dapat disimpulkan bahwa pemahaman kode etik profesi akuntan, kecerdasan intelektual, kecerdasan emosional, dan kecerdasan spiritual secara bersama-sama berpengaruh positif signifikan terhadap perilaku etis mahasiswa akuntansi. Hasil penelitian ini mendukung penelitian terdahulu yang dilakukan oleh Astiana Pamela (2014), Gberegbe, idornigie \& Davies (2016), Risela (2016), Said \& Rahmawati (2018). Astiana Pamela (2014) meneliti tentang Pengaruh Pemahaman Kode Etik Profesi Akuntan terhadap Perilaku Etis pada Mahasiswa Akuntansi Universitas Negeri Yogyakarta. Hasil penelitian Astiana Pamela (2014) menunjukkan bahwa Pemahaman Kode Etik Profesi Akuntan berpengaruh positif terhadap perilaku etis mahasiswa akuntansi Universitas Negeri Yogyakarta. 


\section{JURNAL NOMINAL / VOLUME VIII NOMOR 1 / TAHUN 2019}

Gberegbe, idornigie \& Davies (2016) meneliti tentang Professional code of ethics influence Professional Accounting Practice in Rivers State, Nigeria. Hasil penelitian Gberegbe, idornigie \& Davies (2016) menunjukkan bahwa Professional code of ethics berpengaruh positif terhadap Professional Accounting Practice in Rivers State, Nigeria. Risela (2016) meneliti tentang Pengaruh Kecerdasan Intelektual, Kecerdasan Emosional dan Kecerdasan Spiritual terhadap Persepsi Etis Mahasiswa Akuntansi Mengenai Praktik Akuntansi Kreatif di Perusahaan (Studi pada Mahasiswa Akuntansi Universitas Negeri Yogyakarta). Hasil penelitian Risela (2016) menunjukkan Kecerdasan Intelektual, Kecerdasan Emosional dan Kecerdasan Spiritual berpengaruh positif terhadap Persepsi Etis Mahasiswa Akuntansi. Said \& Rahmawati (2018) melakukan penelitian tentang Pengaruh Kecerdasan Intelektual, Kecerdasan Emosional Dan Kecerdasan Spiritual Terhadap Sikap Etis Mahasiswa Akuntansi (Studi Empiris Pada Mahasiswa Prodi Akuntansi Universitas Negeri Yogyakarta). Hasil penelitian Said \& Rahmawati (2018) menunjukkan kecerdasan intelektual, kecerdasan emosional dan kecerdasan spiritual memiliki pengaruh positif terhadap perilaku etis mahasiswa.

\section{SIMPULAN DAN SARAN}

\section{Simpulan}

Berdasarkan hasil penelitian yang telah dilakukan, maka dapat ditarik kesimpulan sebagai berikut:

a) Pemahaman Kode Etik Profesi Akuntan memiliki pengaruh positif signifikan terhadap Perilaku Etis Mahasiswa Akuntansi Universitas Negeri di Yogyakarta. Hal tersebut dibuktikan dengan hasil pengolahan data yang menunjukkan variabel Pemahaman Kode Etik Profesi Akuntan mendapati angka $\mathrm{t}$ signifikansi sebesar 0,000. Nilai signifikansi sebesar 0,000 lebih kecil dari 0,05, ketika nilai signifikasi yang dihasilkan lebih kecil dari maka dapat ditarik kesimpulan bahwa variabel Pemahaman Kode Etik Profesi Akuntan memiliki pengaruh signifikan terhadap perilaku etis mahasiswa.

b) Kecerdasan Intelektual memiliki pengaruh positif signifikan terhadap Perilaku Etis Mahasiswa Akuntansi Universitas Negeri di Yogyakarta. Hal tersebut dibuktikan dengan hasil pengolahan data yang menunjukkan variabel Kecerdasan Intelektual mendapati angka $\mathrm{t}$ 


\section{JURNAL NOMINAL / VOLUME VIII NOMOR 1 / TAHUN 2019}

signifikansi sebesar 0,000 . Nilai

signifikansi sebesar 0,000 lebih

kecil dari 0,05 . ketika nilai

signifikasi yang dihasilkan lebih

kecil dari maka dapat ditarik

kesimpulan bahwa variabel

Kecerdasan Intelektual memiliki pengaruh signifikan terhadap

Perilaku Etis Mahasiswa.

c) Kecerdasan Emosional memiliki pengaruh positif signifikan terhadap Perilaku Etis Mahasiswa Akuntansi Universitas Negeri di Yogyakarta.. Hal tersebut dibuktikan dengan hasil pengolahan data yang menunjukkan variabel Kecerdasan Emosional mendapati angka $\mathrm{t}$ signifikansi sebesar 0,000. Nilai signifikansi sebesar 0,000 lebih kecil dari 0,05. ketika nilai signifikasi yang dihasilkan lebih kecil dari maka dapat ditarik kesimpulan bahwa variabel Kecerdasan Emosional memiliki pengaruh signifikan terhadap Perilaku Etis Mahasiswa.

d) Kecerdasan Spiritual memiliki pengaruh positif signifikan terhadap Perilaku Etis Mahasiswa Akuntansi Universitas Negeri di Yogyakarta.. Hal tersebut dibuktikan dengan hasil pengolahan data yang menunjukkan variabel Kecerdasan Spiritual mendapati angka $\mathrm{t}$ signifikansi sebesar 0,000. Nilai signifikansi sebesar 0,000 lebih kecil dari 0,05. ketika nilai signifikasi yang dihasilkan lebih kecil dari maka dapat ditarik kesimpulan bahwa variabel Kecerdasan Spiritual memiliki pengaruh signifikan terhadap Perilaku Etis Mahasiswa.

e) Pemahaman Kode Etik Profesi Akuntan, Kecerdasan Intelektual, Kecerdasan Emosional dan Kecerdasan Spiritual memilki pengaruh secara bersama-sama terhadap Perilaku Etis Mahasiswa Akuntansi Universitas Negeri di Yogyakarta.. Hal tersebut dibuktikan dengan hasil pengolahan data yang menunjukkan variabel Pemahaman Kode Etik Profesi Akuntan, Kecerdasan Intelektual, Kecerdasan Emosional dan Kecerdasan Spiritual mendapati angka $\mathrm{F}$ signifikansi sebesar 0,000. Nilai signifikansi sebesar 0,000 lebih kecil dari 0,05. ketika nilai signifikasi yang dihasilkan lebih kecil dari maka dapat ditarik kesimpulan bahwa variabel 


\section{JURNAL NOMINAL / VOLUME VIII NOMOR 1 / TAHUN 2019}

Pemahaman Kode Etik Profesi

Akuntan, Kecerdasan Intelektual,

Kecerdasan Emosional dan

Kecerdasan Spiritual secara

bersama-sama memiliki pengaruh signifikan terhadap Perilaku Etis Mahasiswa.

\section{Saran}

Berdasarkan hasil penelitian serta hal - hal yang terkait dengan keterbatasan penelitian, kiranya peneliti dapat memberikan saran yaitu:

a) Aspek kecerdasan tidak hanya diukur dengan variabel kecerdasan emosional, kecerdasan spiritual, dan kecerdasan intelektual dalam kaitannya dengan Perilaku Etis, melainkan perlu adanya penambahan variabel lain seperti locus of control, gender, pengetahuan dan lain sebagainya. Selain itu, Penelitian selanjutnya juga disarankan untuk melibatkan universitas lainnya, tidak hanya universitas negeri saja.

b) Pada penelitian ini kuesioner yang digunakan dalam mengukur kecerdasan hanya berdasarkan persepsi mahasiswa, untuk penelitian selanjutnya dapat menggunakan instrumen pengukuran yang dikembangkan oleh ahli psikologi dan bisa juga menggunakan soal atau kasus serta wawancara langsung.

\section{DAFTAR PUSTAKA}

Aprilianto, R., \& Achmad, T. (2016). Pengaruh Kecerdasan Emosional, Kecerdasan Intelektual, Dan Love Of Money Terhadap Persepsi Mahasiswa Mengenai Etika Profesi Akuntan. Diponegoro Journal Of Accounting, 1-12.

Davis, J. R., \& Welton, R. E. (1991). Professional ethics: Business students' perceptions. Journal of Business Ethics.

Enofe, A. O., Nakodia, J. O., \& Moruku, J. A. (2014). Ethics and Role of Accountant. European Journal of Business and Management Vol 6, No.27, 144-148.

Ermawati, N., \& Susanti, D. A. (2016). Pengaruh Pemahaman Kode Etik Profesi Akuntan terhadap Perilaku Etis Mahasiswa Akuntansi Universitas Muria Kudus. Buletin Ekonomi Vol. 4, No. 2, 101-208.

Forgas and Negre. (2010). Academic Explantory factors from student. Journal Academic Ethics 8, 217-232

Ghozali, I. (2011). Aplikasi Analisis Multivariate dengan Program IBM SPSS 19. Semarang: Badan Penerbit Universitas Diponegoro.

Goleman, Daniel. (2007). Emotional Intelligence. Jakarta: PT Gramedia Pustaka Utama.

Handayani, S. (2016). Faktor - Faktor Yang Mempengaruhi Perilaku Etis Mahasiswa Akuntansi Universitas Islam Lamongan. Jurnal Ekbis / Vol.XVI / No.2, 809 - 817. 


\section{JURNAL NOMINAL / VOLUME VIII NOMOR 1 / TAHUN 2019}

Hendri, N., \& Suyanto. (2014). FaktorFaktor yang Mempengaruhi Perilaku Etis Profesi Akuntan Pendidik (Studi Empiris pada Perguruan Tinggi di Provinsi Lampung). AKUISISI Vol. 10 No. 2, 21-37.

Husein, U. (2011). Metode Penelitian Untuk Skripsi dan Tesis Bisnis Edisi 11. Jakarta: PT Raja Grafindo Persada.

Irawati, I. (2008). Budaya Menyontek Di Kalangan Pelajar. (Online) diakses tanggal 26 Juli 2018 www.kabarindonesia.com,

Istiqamah, Nur. (2012). Analisis Faktor Faktor Kecerdasan Emosi Mahasiswa Fakultas Psikologi Universitas Islam Negeri Maulana Malik Ibrahim Malang. Skripsi.

Jamaluddin, \& Indisari, R. (2011). Pengaruh Kecerdasan Intelektual, Kecerdasan Emosional, dan Kecerdasan Spiritual terhadap Etika Mahasiswa Akuntansi Fakultas Ekonomi Universitas Tadulako. Pamator Vol. 4 No. 1, 45-56.

Kreitner, R., \& Kinicki, A. (2001). Organizational Behavior, FithEdition, International Edition. Mc Graw-Hill company.inc.

Kurnia, W. (2008) Mendeteksi Kecurangan Mahasiswa pada saat Ujian. Malang : Universitas Brawijaya

Lucyanda, \& Endro. (2012). Faktor-faktor yang Mempengaruhi Perilaku Etis Mahasiswa Akuntansi Universitas Bakrie. Media Research Akuntansi.

Martono, N. (2011). Metode Penelitian Kuantitatif. Jakarta: PT Raya Grafindo Persada.

Melandy, R., \& Nurma, A. (2006). Pengaruh Kecerdasan Emosional terhadap Tingkat Pemahaman Akuntansi, Kepercayaan Diri sebagai Variabel Pemoderasi. Simposium Nasional Akuntansi.

Nugrahaningsih, Putri. (2005). Analisis Perbedaan Perilaku Etis Auditor di KAP dalam Etika Profesi (Studi Terhadap Peran Faktor-Faktor Individual : Locus of Control, Lama Pengalamn Kerja, Gende, dan Equity Sensitivity). SNA VIII Solo, 617-630.

Riasning, N., Datrini , L., \& Putra, I. (2017). Pengaruh Kecerdasan Intelektual, Kecerdasan Emosional Dan Kecerdasan Spiritual Terhadap Sikap Etis Mahasiswa Akuntansi Di Kota Denpasar . Jurnal KRISNA: Kumpulan Riset Akuntansi; Vol. 9, No. 1.

Sagoro, E. M. (2013). Pensinergian Mahasiswa, Dosen, dan Lembaga dalam Pencegahan Kecurangan Akademik Mahasiswa Akuntansi. Jurnal Pendidikan Akuntansi Indonesia Vol. XI No.2, 54-67.

Sari, Gesi Armada. (2016). "Pengaruh Kecerdasan Spiritual, Kecerdasan Emosional, dan Locus of Control terhadap Perilaku Etid Mahasiswa Akuntansi (Studi Empiris Mahasiswa Perguruan Tinggi Negeri Kota Padang)". Padang: Universitas Negeri Padang.

Suryana. (2010). Metode Penelitian Model Praktis Penelitian Kuantitatif dan Kualitatif. Bandung: UPI.

Tika, P. (2006). Budaya Organisasi Dan Peningkatan Kinerja Perusahaan. Jakarta: PT Bumi Aksara.

Umar, M. (2012). Pengaruh Kecerdasan Spiritual Terhadap Etika Profesi Auditor pada Inspektorat Kota Kendari. Jurnal Akuntansi, 53-63.

Zohar, D., \& Ian, M. (2007). Kecerdasan Spiritual. Bandung: Mizan 